Article

\title{
Seabed Morphology and Sedimentary Regimes defining Fishing Grounds along the Eastern Brazilian Shelf
}

\author{
Silvia N. Bourguignon ${ }^{1}$, Alex C. Bastos ${ }^{2, *}$, Valéria S. Quaresma ${ }^{2}$, Fernanda V. Vieira ${ }^{1}$, \\ Hudson Pinheiro ${ }^{3}$ (D), Gilberto Menezes Amado-Filho ${ }^{4}$, Rodrigo Leão de Moura 5 (D) \\ and João Batista Teixeira ${ }^{1}$ (iD \\ 1 Programa de Pós-Graduação em Oceanografia Ambiental, Universidade Federal do Espírito Santo, \\ Vitória 29075-910, Brazil; silviabourg@hotmail.com (S.N.B.); fernanda.vedoato@gmail.com (F.V.V.); \\ jboceano@gmail.com (J.B.T.) \\ 2 Departamento de Oceanografia, Universidade Federal do Espírito Santo, Vitória 29075-910, Brazil; \\ valeria.quaresma@ufes.br \\ 3 Department of Ecology and Evolutionary Biology, University of California Santa Cruz, Santa Cruz, \\ CA 95060, USA; htpinheiro@gmail.com \\ 4 Instituto de Pesquisas Jardim Botânico do Rio de Janeiro, Rua Pacheco Leão 915, Rio de Janeiro 22460-030, \\ Brazil; gilbertoamadofilho@gmail.com \\ 5 Instituto de Biologia and SAGE/COPPE, Universidade Federal do Rio de Janeiro, Ilha do Fundão, \\ Rio de Janeiro 21944-970, Brazil; moura.uesc@gmail.com \\ * Correspondence: alex.bastos@ufes.br; Tel.: +55-027-4009-2878
}

Received: 6 November 2017; Accepted: 3 March 2018; Published: 9 March 2018

\begin{abstract}
Shelf morphology and sedimentary regimes are influenced by processes operating at different temporal and spatial scales and are important records of sea level changes and sediment supply and/or carbonate production. The northern continental shelf of Espírito Santo (Brazil) contains evidence of different sedimentary regimes that distribute diverse and complex marine habitats. Herein, seabed morphology, acoustic images of the seafloor (side scan sonar and sub-bottom profiler), and sediment samples were used to investigate the influence of sedimentary regimes on physical marine habitat distribution. Seabed mapping is also integrated with available data on fisheries to understand the influence of shelf morphology and sedimentology in the usage of distinct fishing gears. The results indicate five morpho-sedimentary facies: terrigenous mud, terrigenous sand, rhodolith beds, carbonate gravel with rhodoliths, and hardground. Through an integrated analysis of the geomorphology and sedimentary distribution, two morpho-sedimentary domains were identified: a sediment-fed shelf adjacent to the Doce River associated with a major mud depocenter and a delta front morphology characterized by gentle slopes and low terrain ruggedness, and a sediment-starved shelf dominated by carbonate sedimentation showing an irregular morphology associated with higher slopes and terrain ruggedness. These contrasting morpho-sedimentary domains are a result of sedimentary responses to sea level fluctuation during Late Quaternary, specially, during the deglaciation processes after the Last Glacial Maximum. The morphological and sedimentary contrasts along the area define the physical habitat distribution. The sediment supply regime area is associated with a terrigenous fine/muddy sedimentation bed, which control the local morphology and favors coastal and delta front progradation. This physical habitat is a well-known shrimp-fishing ground where intense trawling takes place, as well as gillnet fisheries targeting weakfish and croakers. The accommodation regime or low sediment influx area is characterized by carbonate sedimentation associated with hardgrounds and rhodolith beds. In contrast, this physical habitat with scarce sediment supply, facilitates extensive benthic colonization by crustose coralline algae (CCA), which is primarily associated to line fisheries, longlines, and spearfishing. Rhodoliths show a high diversity of CCA and the occurrence of an endemic kelp species. Long-term processes such as relative sea level fluctuations and sediment supply are a legacy for the distribution of benthic
\end{abstract}


habitats, and their resulting morphology can be a surrogate for predicting fishing activities or a first-base analysis for marine spatial planning. Available low-resolution bathymetric datasets can be a powerful tool, if applied with caution and in a regional scale approach. Here, terrain variables (terrain slope and ruggedness) derived from an extensive available (low-resolution and interpolated) bathymetric dataset distinguished two contrasting morphological domains characterized by rugged and smooth/flat seabeds.

Keywords: benthic habitats; shelf morphology; eastern Brazilian shelf

\section{Introduction}

Sedimentation patterns and seabed morphology are controlled by different drivers operating at different spatial and temporal scales. Physical processes, tectonics, climate, sediment input, and relative sea level changes define the sedimentary regimes at continental shelves [1-3].

Morpho-sedimentary features of modern shelves are responses to long-term geological processes. For instance, coastal regions with high sediment supply (depositional regimes) are characterized as prograding coasts and are likely characterized by deltas, coastal plains, and tidal flats. Coastal areas with no sediment supply, or a limited supply (regimes dominated by accommodation), exhibit a geomorphology characteristic of retrograding and starving coasts, defined by erosive processes and features such as cliffs, escarpments, and unfilled river valleys that became estuaries or lagoons [1,4,5].

The role of sedimentary regimes also directly influences the substrate formation and composition. According to [4], many studies have shown that the local geological characteristics are an efficient way to identify physical areas (habitats) in the seabed inhabited by specific biological communities. Important information on seafloor geology and biology can be rapidly acquired by mapping the distribution of benthic habitats. Nichol and Brooke [6] have also pointed out the influence of Late Quaternary transgression on the establishment of distinct seabed habitats.

Herein, we investigate the influence of distinct sedimentary regimes and associated geomorphology on physical habitat and local fisheries. The study area is the central part of the Espirito Santo Continental Shelf (ESCS), East Brazil. This is a multiple-user shelf with distinct stakeholders. The shelf includes a multiple-use Marine Protected Area (MPA), a Marine Wildlife Refuge, a Biological Reserve for nesting marine turtles (both no-take zones), important fishing grounds and artisanal fishing communities, and borders oil and gas rigs along the outer shelf and slope.

\section{Materials and Methods}

The investigation was carried out using a compilation of bathymetric data, and new acoustic and surface sediment data. The fishing ground information was obtained from workshops performed with five local communities and follows the same procedure adopted in [7]. The data were integrated and interpreted using a Geographic Information System (GIS) platform.

\subsection{Study Area}

The Espírito Santo continental shelf is located along the Eastern coast of Brazil. The shelf width varies from 50 to $200 \mathrm{~km}$. Its widest part is known as the Abrolhos Shelf or the Abrolhos Bank [8-10]. To the south of the Abrolhos Bank, the shelf width averages $50 \mathrm{~km}$ and the shelf break occurs at 60 to $80 \mathrm{~m}$ water depth. The Doce river is the main sediment source to the shelf, with an average load of $133 \times 10^{6} \mathrm{t}$ during the rainy season (November to April) [11]. Shelf morphology varies significantly with four distinct regions: Abrolhos shelf, Doce river shelf, Paleovalley shelf, and the wide-southern inner shelf [10]. Here, we focus on contrasting the Doce river shelf with the Paleovalley shelf (Figures 1 and 2). 


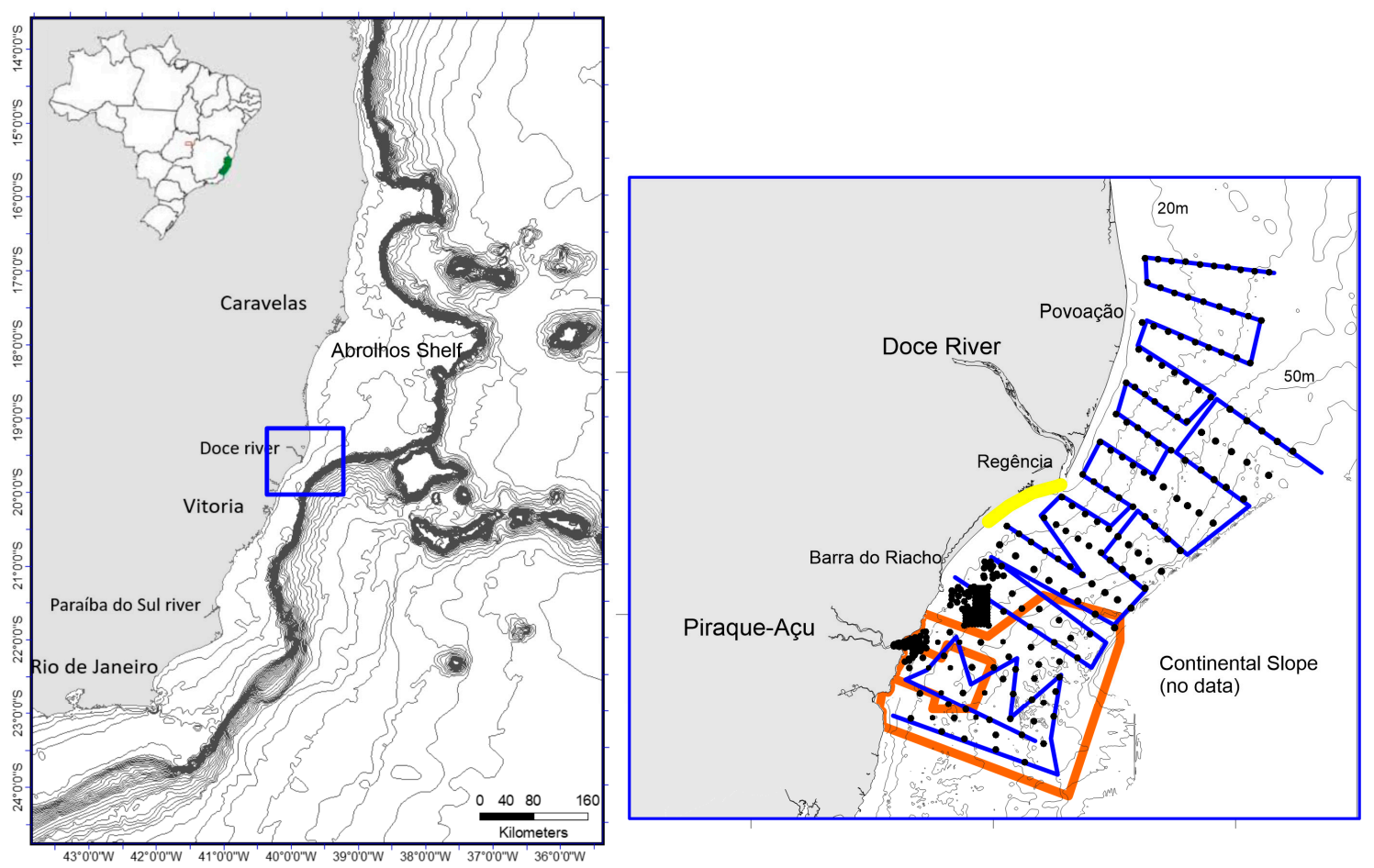

Figure 1. Study area location along the Southeast Brazilian Shelf. Black dots are sampling sites and blue lines are side scan sonar and sub-bottom profiler transects. Orange polygons are the Marine Protected Area-Costas das Algas MPA and the Wildlife Refuge Santa Cruz (inner polygon). Yellow line represents the Comboios Biological Reserve.

\subsection{Data Acquisition}

\subsubsection{Acoustic Imaging}

Data collection was conducted using a Side Scan Sonar Edgetech 4100 with a 560p Digital Acquisition System, which included a 272 TD Towfish with Deep-Tow and a Dual-Frequency (100 and $500 \mathrm{Khz}$ ) Transducer coupled to a Garmin GPS and the Acquisition Software Discover 4100 (Figure 1). Side-Scan Range was set in 200 or $300 \mathrm{~m}$ full swath.

Approximately $1600 \mathrm{~km}$ of side scan data were collected. Acoustic images were processed using the software SonarWiz 5 (Chesapeak Technology, Mountain View, CA, USA). Sonograms were corrected for bottom track and signal attenuation. Processed sonograms were exported as geotiff files $(1 \mathrm{~m}$ pixel resolution) and interpreted in a GIS platform.

\subsubsection{Sub-Bottom Profiling}

Sub-bottom profiles were collected to observe the morphology variations along the shelf using the surface reflector only and not for sub-surface or stratigraphic interpretations. Profiling data were acquired using a sub-bottom profiler, SyQuest StrataBox model, operating at $3.5 \mathrm{KHz}$. Data were received and recorded by the software StrataBox 3.0.4.1 (SyQuest Technology, San Jose, CA, USA) and processed using the software SonarWiz 5 . A total of $1400 \mathrm{~km}$ of sub-bottom profile data were acquired.

\subsubsection{Sediment Sampling}

Sediment samples were collected using a Van Veen grab ( $\mathrm{n}=187$ surficial sediment samples) (Figure 1) and processed for grain size analysis and calcium carbonate content. A laser granulometer (Malvern Mastersizer 2000 (Malvern Panalytical, Nottingham, UK)) was used for particle size analysis 
of the mud fraction and the sieving method was used for the sand fraction. Calcium carbonate content was determined through dissolution with $10 \%$ hydrochloric acid.

The samples were described using the classification proposed by [12], based on carbonate content and grain texture, including: lithoclastic/terrigenous $\left(\mathrm{CaCO}_{3}<30 \%\right)$, lithobioclastic $\left(30\right.$ to $\left.50 \% \mathrm{CaCO}_{3}\right)$, biolithoclastic (50 to $70 \% \mathrm{CaCO}_{3}$ ), and bioclastic $\left(>70 \% \mathrm{CaCO}_{3}\right)$. Lithobioclastic and biolithoclastic are described as mixed sediments.

Seabed images were obtained with a dropcamera consisting of a high-resolution camera (Go Pro Silver 3) attached to a steel frame, and looking vertically down. The base of the frame is a $60 \times 60 \mathrm{~cm}^{2}$.

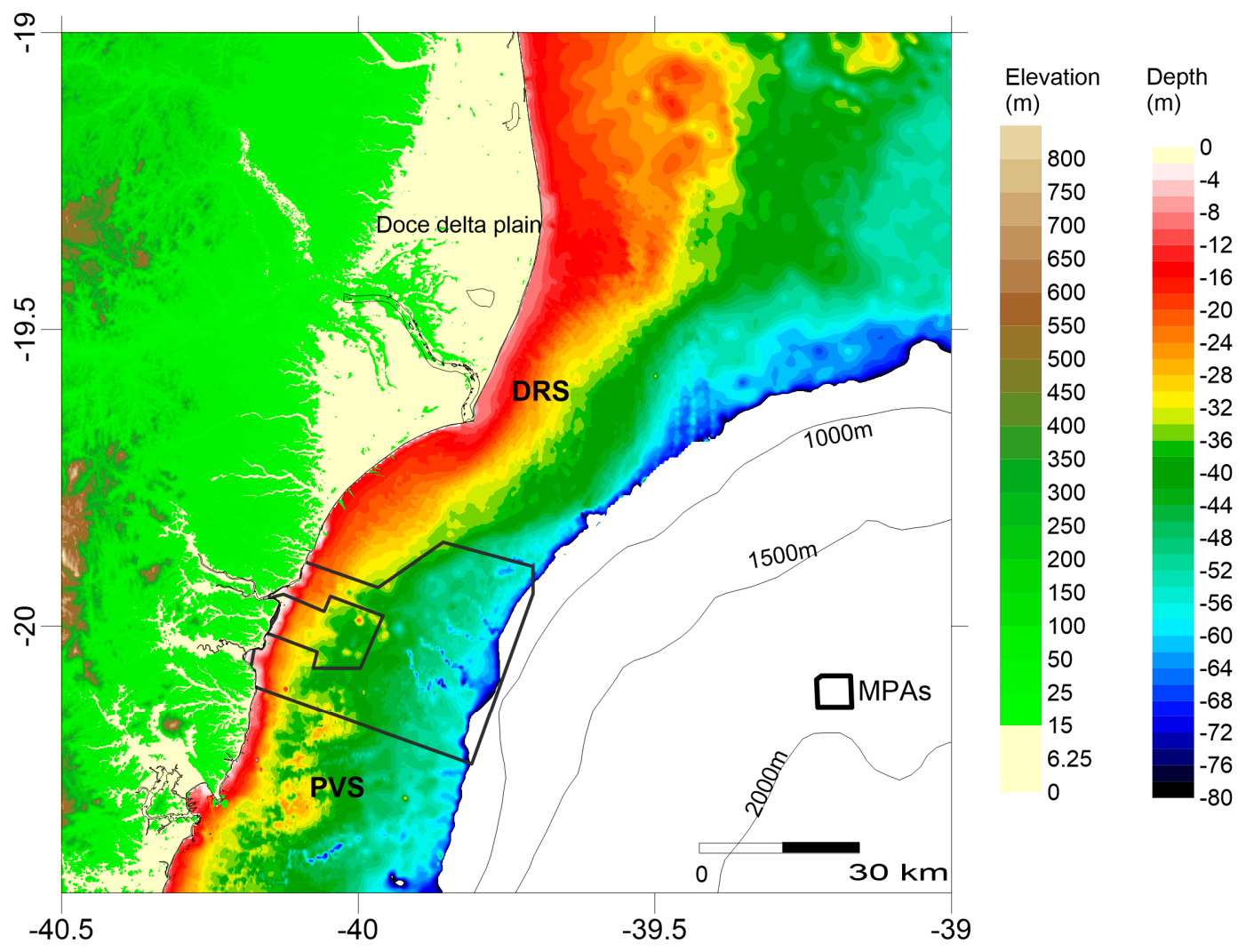

Figure 2. Digital Terrain model of the study region. Continental data was obtained from Topodata database (http: / / www.dsr.inpe.br/topodata/), and bathymetrica data was digitized from sounding sheets provided by the Brazilian Hydrographic Office. The seabed morphology has a spatial resolution of 200m along the continental shelf. PVS: Paleovalley Shelf; DRS: Doce River Shelf. Datum is WGS 84.

\subsection{Shelf Morphology Analysis}

The bathymetric map is the result of a compilation of available data (printed sounding sheets and digital files) from the Brazilian Hydrographic Office. Ten sounding sheets were scanned, digitized, and gridded using Surfer 10 (Golden Software, Golden, CO, USA) and ArcGIS. A total of more than 150,000 points were digitized. Sounding sheets represent data collected by single beam echosounders from the 60 's to the 80 's. Positioning accuracy may vary due to changes in coordinate acquisition systems and methodologies (for more details see [10]). Original datum in the sounding sheets was Corrego Alegre that was transformed and corrected to WGS84, following the available digital data. Original sounding sheets scales varied from 1:10,000 to 1:160,000. All the bathymetric data obtained by the Brazilian Navy follows a protocol, so by not compiling data from other sources (such as satellite derived data), no mismatch was observed. To avoid mismatch, we limited our map to the $100 \mathrm{~m}$ isobaths (available sounding data). A data quality analysis was performed qualitatively considering the regional scale of the study. The only observed suspicious features were broad-scale circular lines to 
the north of the study area. These features seem to be an artifact from the original distribution of the sounding data.

Terrain analysis was carried out using an ArcGIS toolbox, the Benthic Terrain Modeler-BTM [13]. The bathymetric map used for the morphometric calculations has a resolution of $200 \mathrm{~m}$, following the dataset minimum resolution. Slope and Terrain Ruggedness were the input variables used in BTM. Slope represents the inclination of the seabed expressed in degrees and Terrain Ruggedness was calculated using the Vector Ruggedness measure-VRM. This variable represents terrain ruggedness as the variation in three-dimensional orientation of grid cells within a neighborhood, effectively capturing slope and aspect variability into a single measure [14,15]. Slope and VRM calculations is $3 \times 3$ pixels, following the toolbox default. The morphometric analysis was restricted to seafloor morphology, slope, and terrain ruggedness.

\section{Results}

\subsection{Shelf Geomorphology}

The continental shelf presents a contrasting morphology characterized by a flat deltaic lobe with gentle slopes and an irregular relief marked by paleovalleys with greater slopes (Figures 2 and 3). A deltaic lobe is observed associated to the Doce River mouth. In this area, the shelf shows a flatbed (gradients $<0.2^{\circ}$ ) with a minor step at $30 \mathrm{~m}$ depth. Offshore, below $50 \mathrm{~m}$ water depth, an increase in seabed gradient $\left(>0.8^{\circ}\right)$ is observed where the shelf breaks. To the south, the inner shelf still presents a gently sloping seabed to Barra do Riacho, but the $30 \mathrm{~m}$ isobath gets closer to the coastline. In contrast, adjacent to the Piraque Açu River mouth, the seabed morphology is characterized by an irregular bottom with a wide variation in slope (up to $5^{\circ}$ associated with paleovalleys' wall). The shelf morphology in this latter region is characterized by paleovalleys and marine abrasion terraces.
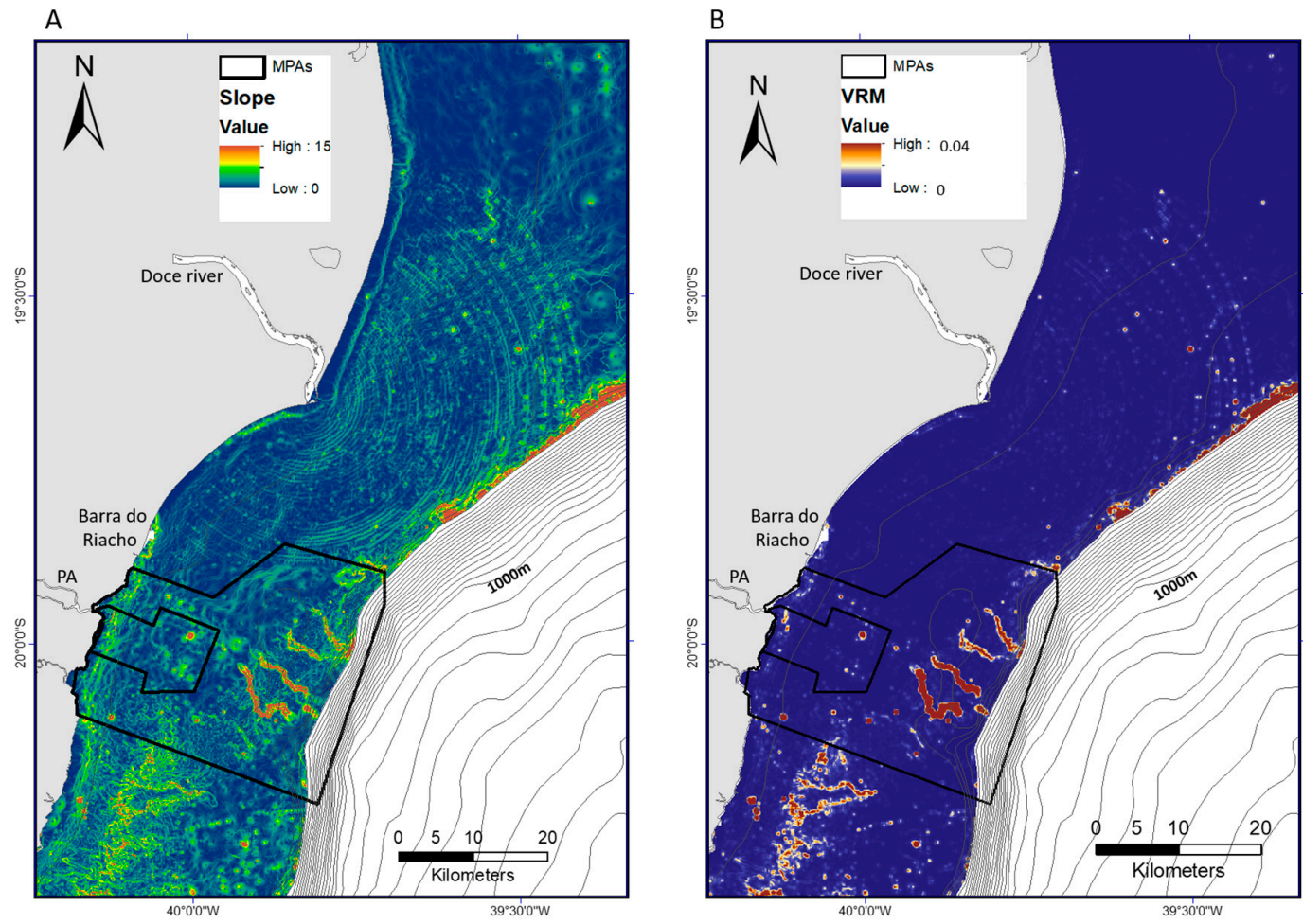

Figure 3. Terrain variables Slope (in degrees) (A) and Terrain Ruggedness; (B) calculated with the Vector Ruggedness Measure using ArcGIS tool Benthic Terrain Modeler (BTM). Datum is WGS 84. Depth contour intervals: $25 \mathrm{~m}$ from 0 to $100 \mathrm{~m}, 50 \mathrm{~m}$ from 100 to $1000 \mathrm{~m}$, and $100 \mathrm{~m}$ from 1000 to $2000 \mathrm{~m}$. 
Analysis of the terrain slope and ruggedness indicate two contrasting areas. The deltaic lobe shelf has a lower variability in slopes with low values of terrain ruggedness. Higher slopes are related to deltaic lobe fronts, dipping seaward. In contrast, the shelf with paleovalleys shows a higher value of terrain ruggedness, with higher slopes.

\subsection{Morpho-Sedimentary Facies_-Physical Habitats}

The shelf presents a heterogeneous substrate in morphologically distinct seabeds. Five morphosedimentary facies (MSF) were identified (Figure 4) based on shelf morphology and sedimentary facies: Terrigenous Mud, Terrigenous Sand, Bioclastic Gravel with Rhodoliths, Rhodoliths, and Coastal Hardground. These MSF are treated herein as physical marine habitats and are described as follows.

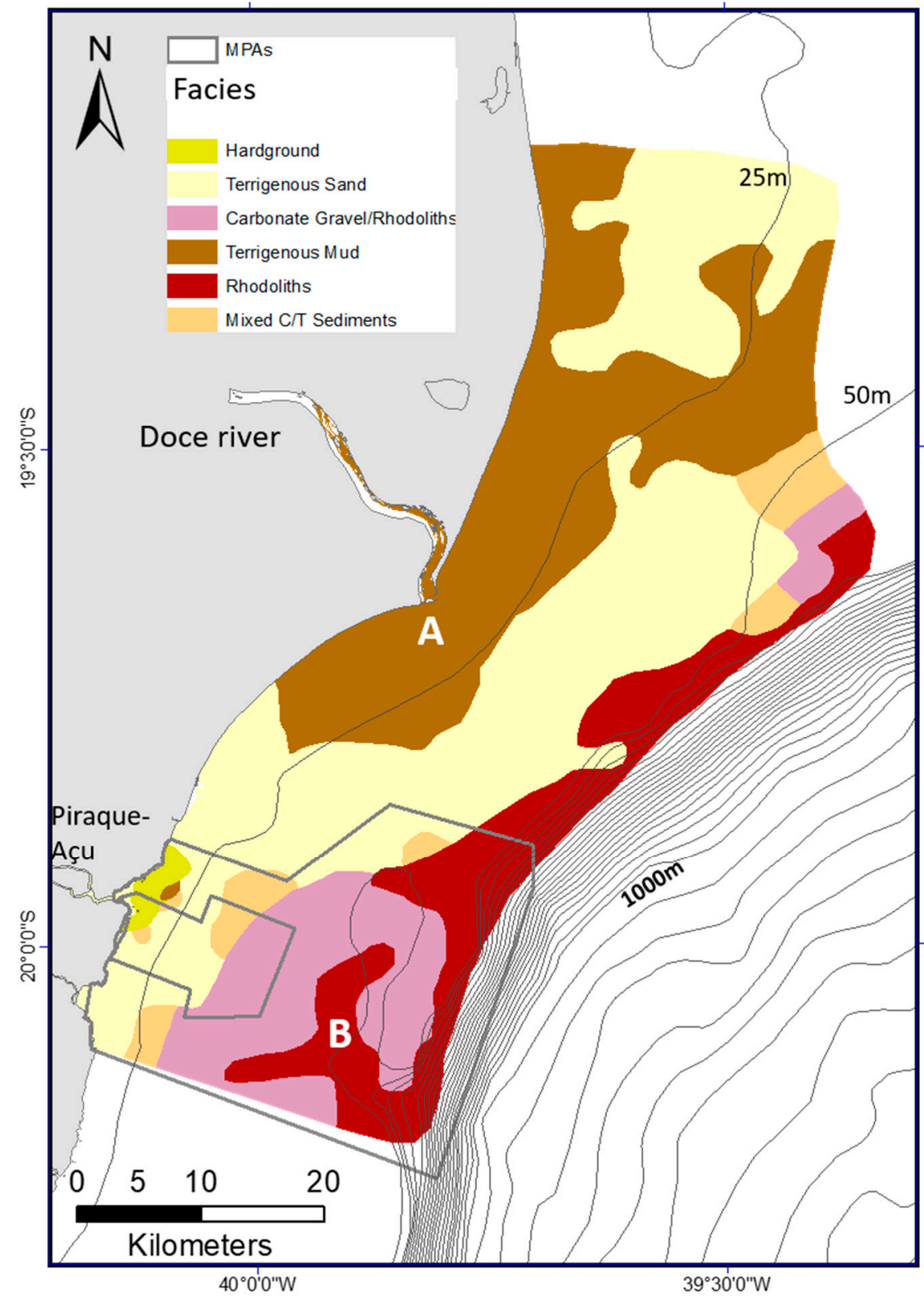

Figure 4. Morpho-sedimentary Facies distribution. (A) and (B) are sonographic and seabed images locations shown in Figure 5. The dataset used to produce this map is shown in Figure 1, including the full side scan sonar and sub-bottom profiler coverage. Depth contour intervals: $25 \mathrm{~m}$ from 0 to $100 \mathrm{~m}$, $50 \mathrm{~m}$ from 100 to $1000 \mathrm{~m}$, and $100 \mathrm{~m}$ from 1000 to $2000 \mathrm{~m}$. 


\subsubsection{Terrigenous Mud}

This domain is primarily observed adjacent to the Doce River mouth, extending throughout the inner shelf; it was also observed in a small stretch of the middle and outer shelf (Figure 4). This habitat comprised $29 \%$ of the study region. The Terrigenous Mud MSF represents the deltaic lobe morphology, with a gentle slope and extending up to 25-30 m water depth (Figure 3). It is composed basically of terrigenous mud and sandy mud. The lithoclastic composition along the coastal region near the Doce River mouth reflects the continental inflow, representing riverine sediments.

\subsubsection{Terrigenous Sand}

The terrigenous sandy bottom MSF comprises the largest habitat of the studied region (41\%). This physical habitat is observed in the inner and mid shelf, but shows a quite irregular distribution (Figure 5). Along the shelf adjacent to the Doce River and to its north, the sandy domain only occurs below $30 \mathrm{~m}$ water depth. Southwards, away from riverine mud influence, sandy bottoms occur along the inner shelf, in shallower waters. In morpho-sedimentary terms, this habitat is again characterized by lithoclastic sands, with grain sizes ranging from coarse to fine, but predominantly medium and fine sands.

A
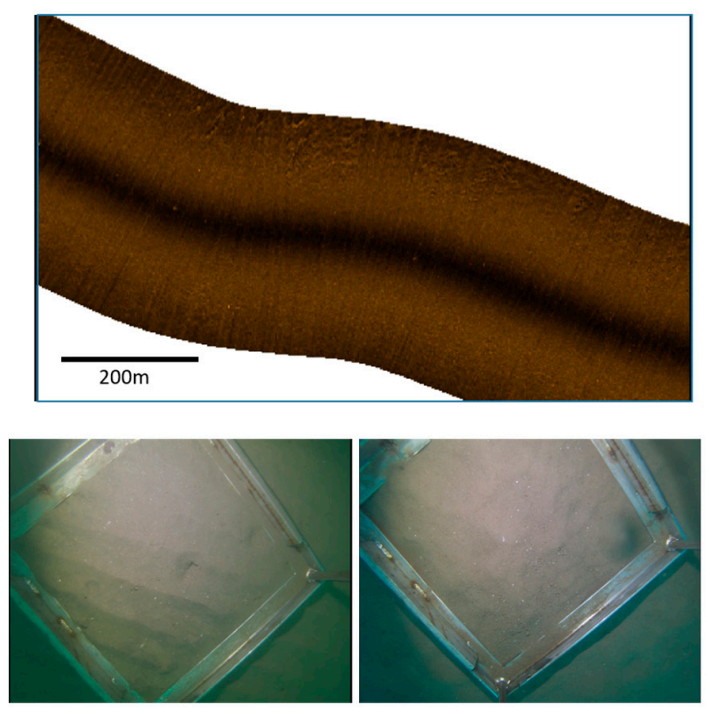

B
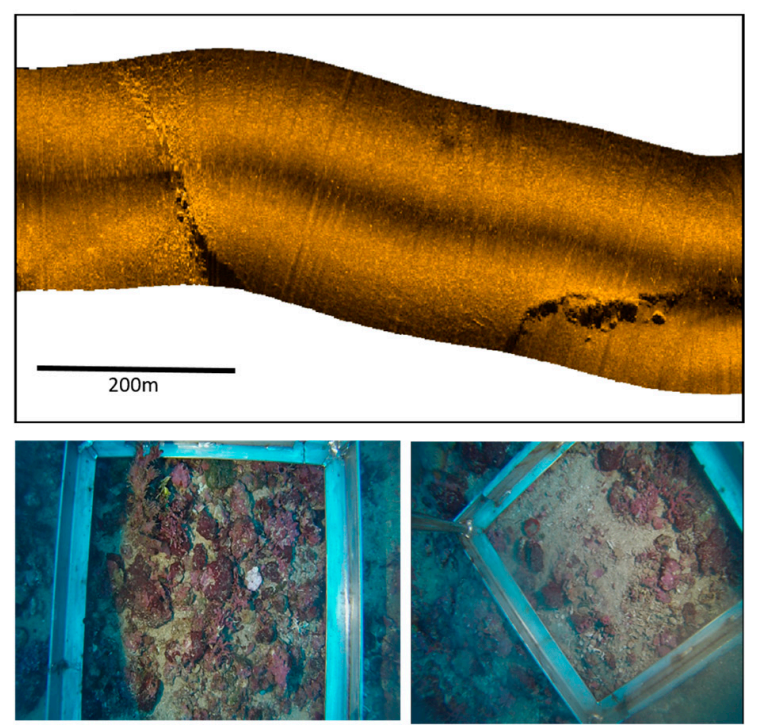

Figure 5. Side scan sonar images and dropcamera seabed frames: (A) Terrigenous fine sediment facies characterized by a homogeneous and low backscatter signal; (B) rhodoliths characterized by a high backscatter signal with acoustic shadows. For images location, see Figure 4.

The occurrence of these sandy bottoms is also associated with a gentle slope and smooth flatbed along the shelf adjacent to the Doce River, but with a more irregular morphology in the inner shelf adjacent to the Piraque Açu river mouth. Remarkably, this domain is related to a second lobe-like morphology feature along the mid-outer shelf adjacent to the Doce River mouth. In this area, this MSF occurs offshore from the mud deposit (Figure 4).

\subsubsection{Rhodolith Beds}

The Rhodolith Beds MSF were consistently observed in the outer shelf up to the shelf break (Figure 4), composing $14 \%$ of the study area. This facies is represented by a gravelly carbonate fraction, composed from granules to rhodoliths. The extensive rhodolith area indicates that terrigenous sedimentation influence in this region is negligible, since the CCA that form rhodoliths are more likely to grow in areas with low sedimentary inflow [16]. 
The occurrence of a rhodolith habitat is related to water depth and is adjacent to an irregular bottom morphology. Rhodolith beds are associated to a strong acoustic signature in side scan sonar data. This habitat predominates in depths $>40-45 \mathrm{~m}$, being associated with paleochannels and terraces, mainly along the southern part of the shelf. Locally, the formation of hardground or crusts by coalescence of CCA is also observed. Individual rhodoliths exhibited a typical nodular shape, with surface irregularities and diameters ranging between 1 and $10 \mathrm{~cm}$.

\subsubsection{Bioclastic Gravel with Rhodoliths}

The bioclastic gravel with rhodoliths MSF composes $16 \%$ of the study area and is located along much of the shelf adjacent to the Piraque Açu river mouth, within the Costa das Algas Marine Protected Area (Figure 1). This domain is characterized by coarse fragments of biogenic material, including CCA and carbonate skeletons (including shell fragments). Rhodoliths occur along this domain, intermingled with bioclastic gravel. The seafloor is dominated by gravelly sediments and rhodoliths, forming a very irregular morphology, and is associated to paleochannels and hardground terraces.

\subsubsection{Coastal Hardground}

Coastal hardground is composed mainly by ferrigenous crusts (lateritic crusts) incrusted by organisms. It was only observed at the mouth of the Piraquê-Açu river, although it is a common feature in the intertidal zone along the southern coast of the area. These reefs are formed initially by sediment laterization, followed by marine abrasion during different cycles of sea level changes. Once a hardground, it becomes a substrate for incrustation.

\subsection{Fishing Activities}

Distribution of fishing grounds was obtained from workshops performed with five local communities. Five major fishery types were described (Table 1).

Table 1. Fishery types and ground areas. Dive includes spearfishing and shellfishing, and Gillnet includes bottom fishing net and fishing net.

\begin{tabular}{lccccc}
\hline & \multicolumn{5}{c}{ Area (ha) for Each Fishery Type } \\
\hline \multirow{3}{*}{ Fishing Ground } & Trawlling & Longline & Angling & Dive & Gillnet \\
& 40,844 & 47,003 & 190,287 & 10,845 & 92,055 \\
\hline
\end{tabular}

The relationship between fisheries with distinct MSF and the percentage of each fishery activity over each habitat domain is shown in Figure 6. Most trawling (96\%) and all bottom-associated gillnet fisheries are carried out in the terrigenous sediment flatbed domains. Over the carbonate domain with higher terrain ruggedness and slope, fisheries activities are related to line and longline fishing, as well as to spearfishing. Across the Doce river inner shelf, for example, the areas identified as muddy bottom habitats are associated with shrimp trawling artisanal fisheries [17], as well as bottom-associated gillnet fisheries targeting carnivorous fishes such as sciaenids, carangids, and elasmobranchs [18]. According to [19], from Barra do Riacho to the mouth of the Doce River, trawling is performed by both artisanal and industrial boats, mostly targeting shrimp. In a more recent survey from workshops with local fishermen, [20] also highlighted that in this southern region adjacent to the mouth of the Doce River, shrimp fishing is widespread due to the concentration of sandy-muddy bottoms, whereas on seafloors with a muddy composition, whiting fishing is more frequent. Along this stretch, the fishing area is continuous and is used from the coastline to the $40 \mathrm{~m}$ isobaths. 


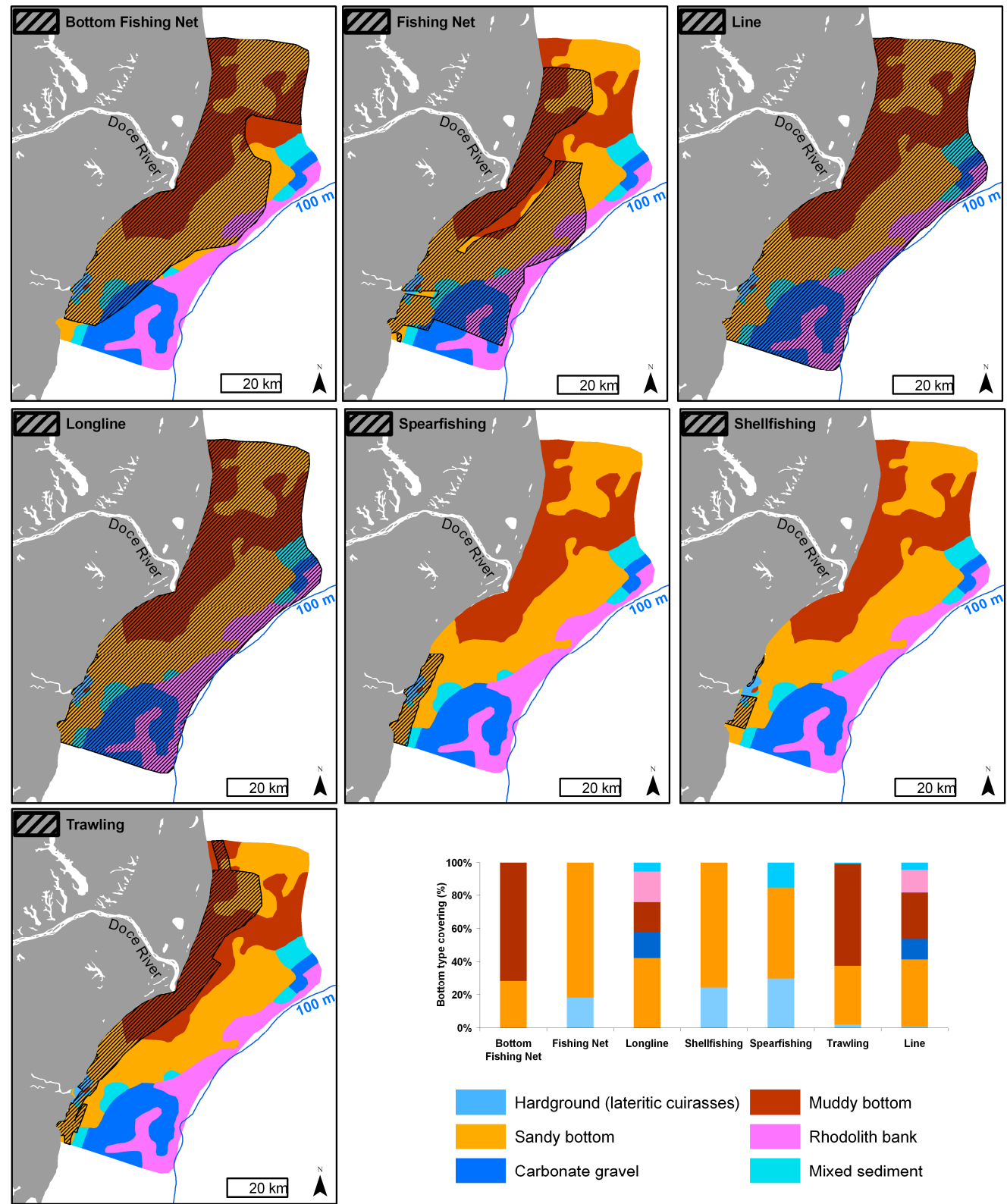

Figure 6. Relationship between different fisheries types and sedimentary facies. The graph shows the percent cover of each fishery in the distinct sedimentary domains.

\section{Discussion}

The five MSF indicate the occurrence of two main sedimentary regimes: terrigenous supply regime and accommodation/carbonate sedimentation regime. The sedimentation pattern along the inner shelf adjacent to the Doce River is characterized by modern terrigenous sediment input, forming a submarine muddy delta lobe, representing a supply regime area. To the south and offshore from the terrigenous mud deposits, very low or no significant sediment input takes place. Shelf morphology is rather irregular due to erosion or resembles a relict morphological feature, characterizing an accommodation regime [5]. This area is characterized by relict/palimsestic sediments (terrigenous sands) and mixed sediments. Along the outer shelf and parts of the mid shelf, the sedimentary regime is predominantly carbonate, with development of bioclastic gravels and rhodolith beds. It is noteworthy that the carbonate sedimentation develops over an accommodation area characterized by low sediment input and relict morphological features, such as unfilled paleochannels, formed during 
the last lowstand [10]. Thus, carbonate sedimentation is defined by biologically-controlled precipitation (e.g., crustose coralline algae-rhodoliths), but also by bioclastic particles transport and deposition.

The distribution of these regimes is influenced by processes that operate at different time and spatial scales. Typically, sedimentation is controlled by a combination of autogenic and allogenic processes, which determine the distribution of elements and geological variables in a depositional system $[1,5]$. Shelf morphology, at this scale, is a product of long-term processes, such as sea level changes.

The alteration of such controls introduces an imbalance between sediment supply and modifications within the basin, characterizing local sedimentary regimes and leading to depositional processes of aggradation or erosion, as well as coastal displacement $[1,5,21]$. Typically, if the rates of sediment supply are higher than sea level fall, the sedimentary regime is dominated by supply and accompanied by progradation or shoreline regression [1]. Conversely, under no, or minimal sediment supply, the trend is erosion, modification of the shoreline by wave action and, therefore, potential shoreline transgression. This process establishes a sedimentary regime dominated by accommodation accompanied by retrogradation of the coast and marine facies overlying the terrigenous facies $[1,5,22]$.

The sedimentary facies distribution is characterized by lithoclastic (terrigenous), mixed, and bioclastic (carbonate) sediments, and is closely associated to seabed morphology (Figure 6). Terrigenous mud and sand (primarily sandy mud and medium to fine sands) are observed along the deltaic gentle slope flatbeds, with low terrain ruggedness. A muddy patch is found adjacent to the river mouth. Areas with mixed, biolithoclastic, or lithobioclastic sedimentation are also identified; deposits were less common and might represent a transition from terrigenous to carbonate sedimentation. These sediments show a wide range of grain sizes, from sandy mud to gravelly sands. Bioclastic sediments comprise a higher concentration of gravelly and sandy fractions, which dominate the mid-outer shelf in the southern portion of the study area and the outer shelf in its northern part. Rhodolith beds occur along the outer shelf. These carbonate-dominated sediments are associated with higher terrain ruggedness, which is expressed by an irregular shelf morphology with marine abrasion terraces and paleovalleys.

Thus, combining spatial changes in bed slope, which represents the contrasting shelf geomorphology, with sedimentation regimes (terrigenous and carbonate), we can define two major Morpho-Sedimentary Domains (MSD): Terrigenous (terrigenous mud + terrigenous sand facies) and Carbonate (rhodoliths + bioclastic gravel with rhodoliths facies). The Carbonate MSD is related to higher slope, terrain ruggedness, and deeper depths, with carbonate-dominated facies, whereas the Terrigenous MSD is associated with gently inclined bottom, low ruggedness, and shallower areas with siliciclastic sediments. The two MSD are clearly observed in Figure 7, where long and crossshelf bathymetric profiles show changes in morpho-sedimentary characteristics. MSD distribution in relation to a terrain variable (slope) is shown in Figure 8.

In the Doce River area, the sedimentary input is dominated by supply, characterized by the progradation of the coastline. Typically, the deposits in the region are composed of fine to very fine terrigenous sediments. Such deposits are described as regressive deposits associated to high sediment input, promoting rapid accumulation. Other parts of the Brazilian shelf also exhibit a similar sedimentary regime and morphological characteristics, being dominated by deltas in between starved areas [23]. Four main deltas occur (from south to north): the Paraíba do Sul river delta, Doce river delta, Jequitinhonha river delta, and São Francisco river delta. Sedimentation patterns in the adjacent shelf of these deltas are very similar. Along the narrow eastern Brazilian shelf, [24] identified fine terrigenous sediment facies associated to river mouths or shelf incised valleys and carbonate dominated facies. For the São Francisco River shelf (AL), [25] described a progradation zone in the shelf, characterized by mud and muddy sands.

The presence of muddy bottom and terrigenous sand habitats in the study region suggests that the geological characteristics of the substrate drive demersal and benthic communities structured by scavengers. Substrates with unconsolidated marine deposits are typically associated with flat bottoms and a thick sedimentary cover [26], which was identified in both domains, particularly in 
the submarine delta lobes of the Doce River. Such morpho-sedimentary properties attract scavenging communities (e.g., shrimps, crabs, catfishes), since the thickness of the terrigenous sediments is directly associated with the levels of organic carbon supplied. In the coastal zone, this carbon is partially recycled and partially deposited with the terrigenous sediments [26]. Such sediments with high concentration of organic carbon provide an important food supply for high-biomass demersal and benthic communities.
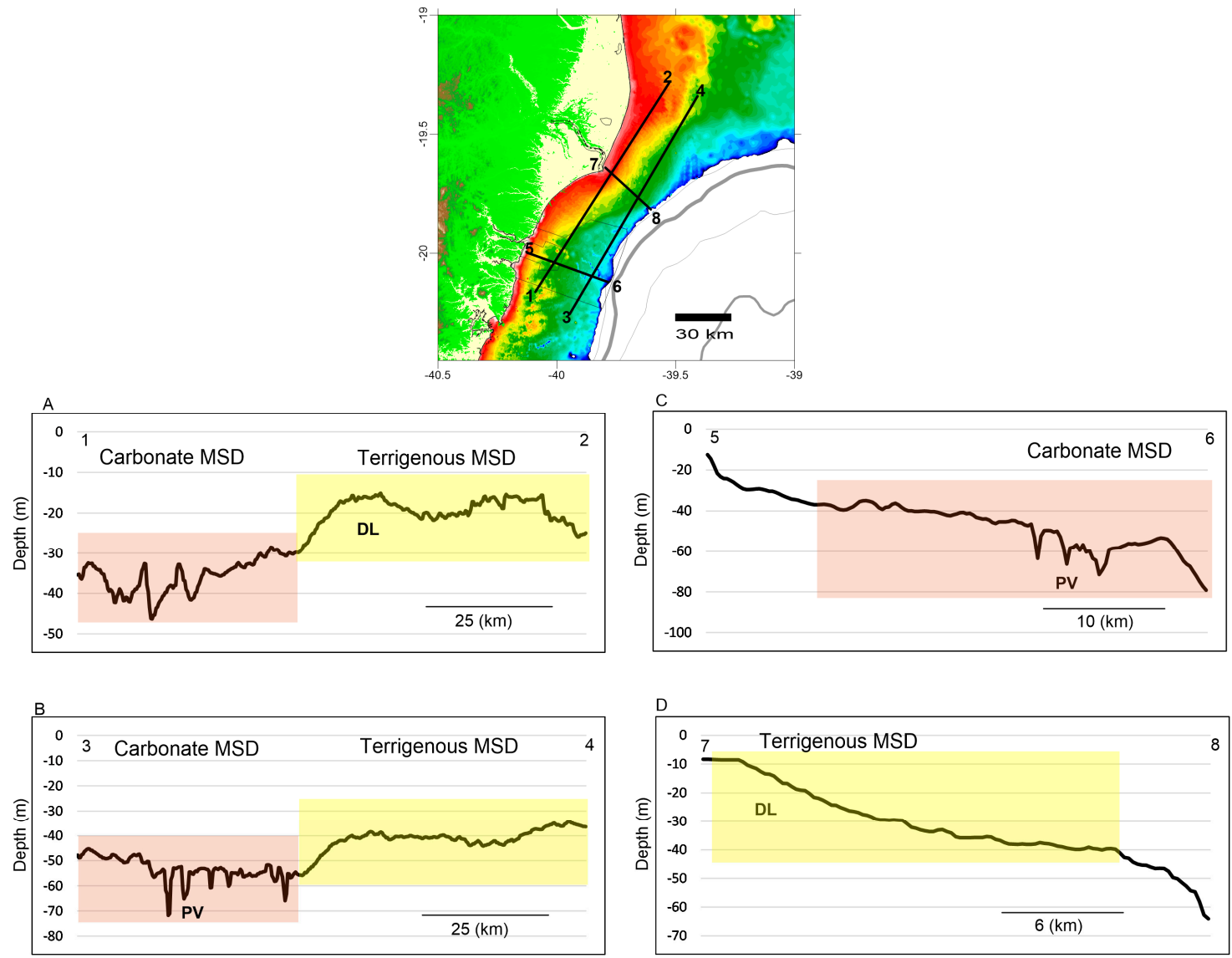

Figure 7. Long-shore and cross-shelf bathymetric profiles and associated MSD. PV-paleovalley; DL-delta front; (A) long-shore, inner shelf bathymetric profile showing the morphological and faciologic transition between MSDs, (B) long-shore, outer shelf bathymetric profile showing the morphological and faciologic transition between MSDs, (C) cross-shelf bathymetric profile along the Carbonate MSD, (D) cross-shelf bathymetric profile along the Terrigenous MSD.

Unlike the Doce River region, the southern section is characterized by a contrasting sedimentary regime (Figure 4). The continental shelf is deficient in sediment supply, with very low or negligible inflow, and is characterized by a sedimentary accommodation-dominated regime. The seabed habitats comprise coarse sediments, predominantly coarse sand, bioclastic gravel fractions, and extensive occurrence of rhodolith beds. These aspects support the transgressive characteristics in the area [10].

With the rapid rise in sea level, waves and tides eroded the coastline and shoreface substrates, which generated coarse particle deposits that were later modified and produced low sedimentation rates [5,22]. The low volume of accumulated and deposited sediments characterizes the inner and middle shelf of the region as a "starved" shelf with thinner deposits, coarse relict sediments, and carbonate sedimentation related to the observed habitats (rhodolith beds) [10].

Thus, the irregular morphology and the presence of paleovalleys are a result of marine transgressions under negligible sediment input. These unfilled paleochannels control the habitat morphology and likely act as sediment pathways from the shelf to the slope. A similar situation was 
recorded in the central continental shelf in Bahia, Northeastern Brazil [27], which was classified as a starving shelf. This classification was especially evident for the middle and outer portions, where several valleys dissecting the shelf were observed. In south Espírito Santo, based on surveys by [7], the accommodation system also dominates this portion of the shelf, which comprises low terrigenous mud and sand contents, while carbonate gravel and rhodolith dominate the shelf.

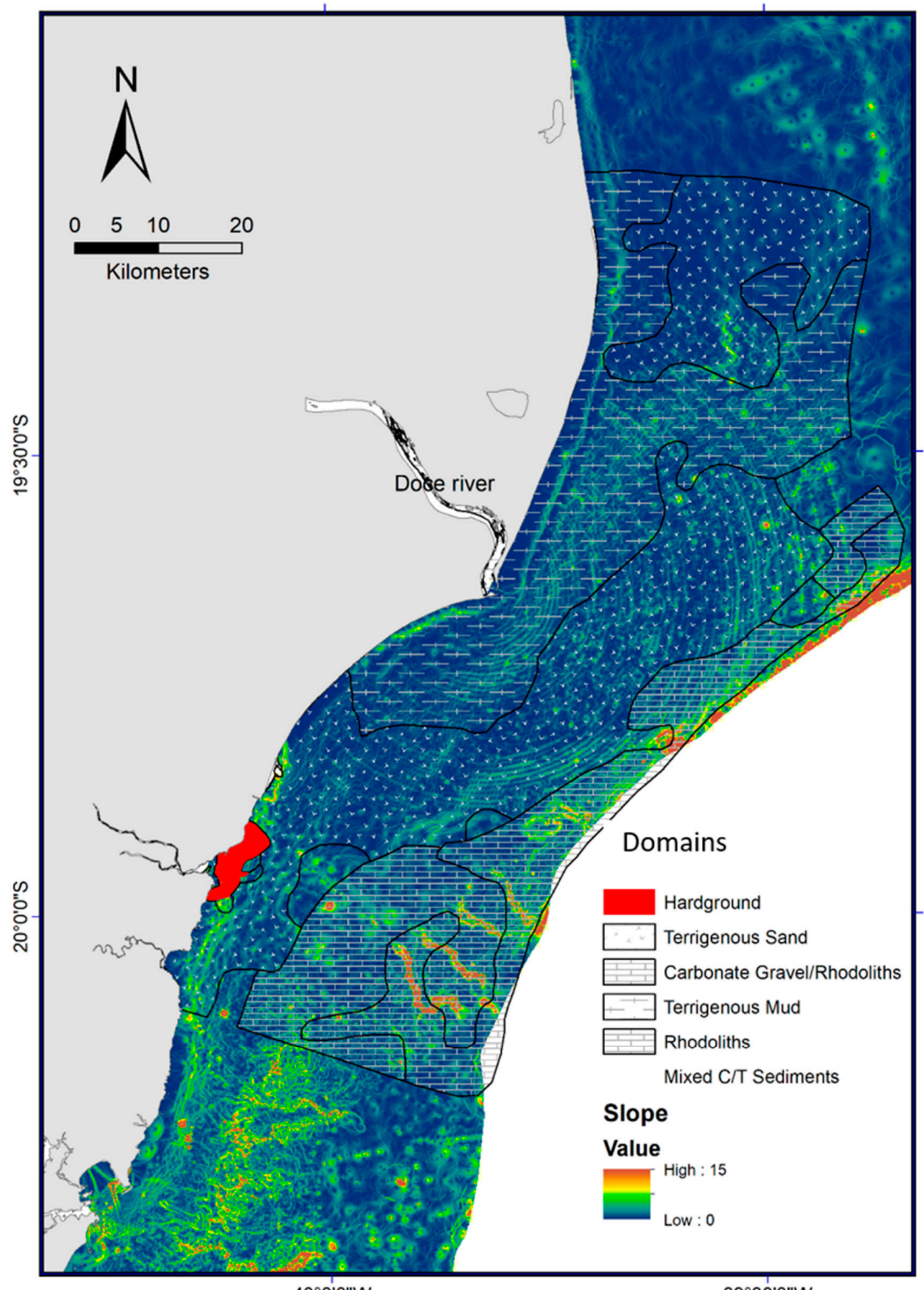

$40^{\circ} 0^{\prime} 0^{\prime \prime} \mathrm{W}$

$39^{\circ} 30^{\prime} 0 " \mathrm{~W}$

Figure 8. Map combining carbonate and terrigenous domains with a terrain variable (slope). 
The outer shelf of the studied area was dominated by an extensive rhodolith bed. The development of rhodolith beds along the eastern Brazilian shelf results from the rising sea level over the last 20 thousand years [28]. The development of the extensive accumulations of CCA on the tropical Brazilian shelf is attributed to ecological conditions that include low terrigenous input, good light penetration, efficient water circulation, and a relatively stable substrate [28,29]. Furthermore, the structural pattern of these rhodolith beds along depth gradients may also be related to the combined extension and inclination of the continental shelf [30,31]. In Abrolhos, for example, [32,33] the geological characteristics of the shelf, combined with meteoceanographic constraints, promote favorable conditions for rhodolith growth.

Rhodoliths highly influence the associated organisms and increase biodiversity, primarily by increasing structural complexity [30,34], being therefore considered ecosystem engineers [16]. The rhodolith structure provides a hard surface and three-dimensional substrate that serves as a microhabitat for a wide variety of associated invertebrates, algae and fish, many of which are economically and ecologically important [35-37]. Moreover, rhodoliths represent one of the world's largest deposits of calcium carbonate $\left(\mathrm{CaCO}_{3}\right)$, with an estimated $2 \times 10^{11} \mathrm{t}[28,38]$.

The Terrigenous Mud and Terrigenous Sand shelter less diverse benthic assemblages. In the region near the coastal plain of the Doce River, the benthic habitat is not amenable to benthic marine macroalgae fixation, [37] due to the large continental sediment contribution that prevents settlement and development. In contrast, the region further south, adjacent to the Piraque-Açu River, is considered the richest Brazilian region in algal species, with CCA species endemism $[39,40]$ in southern Espírito Santo. Bioclastic Gravel with Rhodoliths and Rhodoliths beds represent an important habitat for several commercially important and threatened fish species [41]. These ecosystems also provide an important habitat for benthic communities and maintain $25 \%$ of the known macroalgae species on the Brazilian coast [30]. Thus, it appears that the low sedimentary inflow in the Aracruz and adjacent shelves facilitates the colonization of vast rhodolith beds, conversely to the inner shelf adjacent to the Doce River. Recent studies highlight the presence of 74 fish species in mesophotic rhodoliths beds, including an endemic fish genus and many endangered species [42]. At least 18 commercially important species are associated with this habitat, most of them captured by lines and longlines, such as porgies (Pagrus pagrus and Calamus sp.), snappers (Lutjanus buccanella, L. cyanopterus and Ocyurus chrysurus), groupers (six species), and amberjacks (Seriola spp.) [42].

The shelf morphology and sedimentary distribution over the study area is strongly controlled by long-term processes, such as sea level changes and sediment input. Thus, fishing grounds are also controlled or related to this long-term response, i.e., a legacy of the Late Pleistocene-Holocene sedimentary evolution. Short-term and seasonal oceanographic processes are important, especially in terms of water column variability (temperature, salinity, turbidity, dissolved oxygen, primary production, etc.) and bed disturbance. However, the physical setting controlling the benthic habitat is the seabed morphology and sediment distribution, which is related to the geological background.

Seabed characterization is a major source of environmental information [7], such as environmentally relevant areas and fishing grounds. For instance, trawling activities can be less impacting in the northern areas where muddy bottoms are more widespread than in the southern area. Angling and gillnetting in the south area can help shift the currently high fishing effort over the shallow lateritic cuirasses towards less fished rhodolith bed and sand bottom. In this context, understanding the sedimentation regime is important because it is a key factor that directly influences resources' distribution. Moreover, shelf morphology and terrain analysis reflect sedimentation regimes in the study area and can be used as a primary surrogate by managers and decision-makers in a first step for marine spatial planning.

Finally, it is also relevant to highlight the importance of using available bathymetric datasets, even if they are old or interpolated, but reach minimum data quality. High-resolution multibeam bathymetric models are not commonly available for regional seabed analysis. In this case, available sounding sheets or regional digital single-beam data are the only sources for a morphological or 
geomorphological analysis of the continental margin. Here, we have used an extensive dataset with a minimum quality and a reasonable accuracy to conduct a terrain analysis from an interpolated digital terrain or bathymetric model. The available data and the derived map are powerful tools for a first or basic analysis for marine management, so the use of these sounding sheets became a must in Brazil and elsewhere. Results can be severely impacted by eventual inaccuracies of the data, such as, errors in data positioning due to changes in technology, datum transformation, or distortion from the printed sounding sheets, if caution is not applied. The results, either terrain variables or the digital terrain model, must be used with caution as limitations apply for seabed morphometric analysis. Usually, interpolated digital terrain models will be able to separate distinct morpho-sedimentary domains in a regional scale [43], but can be very inaccurate if one decides to undertake a high-resolution analysis. Herein, we applied the available dataset with caution and carried out a regional analysis distinguishing end-terms morpho-sedimentary domains; rugged from flat seabeds. The regional contrasting regimes and seabed morphology allowed this interpretation, showing that, in a regional scale, available bathymetric dataset can be very useful.

\section{Conclusions}

Morphological and sedimentological analysis of a sedimentary regime-contrasting continental shelf revealed the role played by long-term processes in marine physical habitat distribution. Areas with sediment supply regime exhibited physical habitats associated with terrigenous fine sedimentary facies with local prograding morphology. Terrigenous sedimentation was associated with gently inclined beds with low terrain ruggedness. Areas with very low sediment input represent the accommodation regime, in this case, a carbonate dominated shelf. Physical habitats are characterized by bioclastic gravels and living rhodoliths, occurring in deeper areas with irregular morphology, higher slopes, and terrain ruggedness. These distinct habitats explain fishery systems and exploited resources. Understanding the prevailing oceanographic and biological conditions is essential for the management of marine resources, but the study of the geological processes that drive sedimentation regimes allows for a broad understanding of the origin and distribution of marine habitats and fishery resources. In the studied region, the contrasting geomorphology is a reliable surrogate for fishing activities. Terrain analysis involving spatial variability in slope and ruggedness may be more widely used by managers and planners, not only as indicatives of sedimentary regimes, but also for mapping fishing grounds and for designing more effective biodiversity assessments. Moreover, if used with caution, available low-resolution bathymetric datasets can be applied for geomorphometric analysis in a regional scale approach. Here, terrain variables (terrain slope and ruggedness) derived from an extensive available (low-resolution and interpolated) bathymetric dataset distinguished two contrasting morphological domains characterized by rugged and smooth/flat seabeds.

Acknowledgments: Authors want to thank FAPES (Universal and PPE Gerenciamento Costeiro) for two Research Grants that funded data compilation and acquisition and CAPES (Ministry of Education, Brazilian Government) for providing a scholarship for the first Author (SNB). This manuscript is a contribution to the Long-term Ecological Program (PELD ABROLHOS, CNPq/FAPES/CAPES). Financial support for part of the data acquisition was from PD\&I ANP/BRASOIL (proc. 48610.011015/2014-55). We thank the reviewers and the Academic editor for their valuable comments that improved the manuscript.

Author Contributions: Silvia N. Bourguignon, Alex C. Bastos, Valéria S. Quaresma, Fernanda V. Vieira, Hudson Pinheiro and João Batista Teixeira have contributed equally to the research and manuscript writing. Rodrigo Leão de Moura and Gilberto Menezes Amado-Filho contributed with final data analysis and manuscript discussion and revision.

Conflicts of Interest: The authors declare no conflict of interest. The founding sponsors had no role in the design of the study; in the collection, analyses, or interpretation of data; in the writing of the manuscript, and in the decision to publish the results. 


\section{References}

1. Catuneanu, O. Principles of Sequence Stratigraphy; Elsevier Science: Amsterdam, The Netherlands, 2006; p. 386.

2. Cowell, P.J.; Thom, B.G. Morphodynamics of coastal evolution. In Coastal Evolution: Late Quaternary Shoreline Morphodynamics; Carter, R.W.G., Woodroffe, C.D., Eds.; University Press: Cambridge, UK, 1994; p. 540.

3. Sternberg, R.; Nowell, A.R.M. Continental shelf sedimentology: Scales of investigation define future research opportunities. J. Sea Res. 1999, 41, 55-71. [CrossRef]

4. Harris, P.T.; Baker, E.K. 1-Why Map Benthic Habitats? In Seafloor Geomorphology as Benthic Habitat; Elsevier: London, UK, 2012; pp. 3-22.

5. Swift, D.J.P.; Phillips, S.; Thorne, J.A. Sedimentation on Continental Margins, IV: Lithofacies and depositional systems. In Shel and Sandstone Bodies: Geometry, Facies and Sequence Stratigraphy; Swift, D.J.P., Oertel, G.F., Tillman, R.W., Thorne, J.A., Eds.; Wiley: Hoboken, NJ, USA, 1991; pp. 89-152.

6. Nichol, S.L.; Brooke, B.P. Shelf habitat distribution as a legacy of Late Quaternary marine transgressions: A case study from a tropical carbonate province. Cont. Shelf Res. 2011, 31, 1845-1857. [CrossRef]

7. Teixeira, J.B.; Martins, A.S.; Pinheiro, H.T.; Secchin, N.A.; Leão de Moura, R.; Bastos, A.C. Traditional ecological knowledge and the mapping of benthic marine habitats. J. Environ. Manag. 2013, 115, 241-250. [CrossRef] [PubMed]

8. D'agostini, D.P.; Bastos, A.C.; Dos Reis, A.T. The modern mixed carbonate-siliciclastic abrolhos shelf: Implications for a mixed depositional model. J. Sediment. Res. 2015, 85, 124-139. [CrossRef]

9. Moura, R.L.; Secchin, N.A.; Amado-Filho, G.M.; Francini-Filho, R.B.; Freitas, M.O.; Minte-Vera, C.V.; Teixeira, J.B.; Thompson, F.L.; Dutra, G.F.; Sumida, P.Y.G.; et al. Spatial patterns of benthic megahabitats and conservation planning in the Abrolhos Bank. Cont. Shelf Res. 2013, 70, 109-117. [CrossRef]

10. Bastos, A.C.; Quaresma, V.S.; Marangoni, M.B.; D’Agostini, D.P.; Bourguignon, S.N.; Cetto, P.H.; Silva, A.E.; Filho, G.M.A.; Moura, R.L.; Collins, M. Shelf morphology as an indicator of sedimentary regimes: A synthesis from a mixed siliciclasticecarbonate shelf on the eastern Brazilian margin. J. S. Am. Earth Sci. 2015, 125-136. [CrossRef]

11. Oliveira, K.S.S.; Quaresma, V.S. Temporal variability in the suspended sediment load and streamflow of the Doce River. J. S. Am. Earth Sci. 2017, 78, 101-115. [CrossRef]

12. Larsonneur, C. La cartographie de's dépots meubles sur le plateau continental français: Méthode mise du points et utilisée em Manche. J. Recherche Oceanogr. 1977, 2, 34-39.

13. Wright, D.J.; Pendleton, M.; Boulware, J.; Walbridge, S.; Gerlt, B.; Eslinger, D.; Sampson, D.; Huntley, E. ArcGISBenthic Terrain Modeler (BTM), 3.0; NOAA Coastal Services Center, Massachusetts Office of Coastal Zone Management: Boston, MA, USA, 2012.

14. Sappington, J.M.; Longshore, K.M.; Thompson, D.B. Quantifying landscape ruggedness for animal habitat analysis: A case study using bighorn sheep in the Mojave Desert. J. Wildl. Manag. 2007, 71, 1419-1426. [CrossRef]

15. Jerosch, K.; Kuhn, G.; Krajnik, I.; Scharf, F.K.; Dorschel, B. A geomorphological seabed classification for the Weddell Sea, Antarctica. Mar. Geophys. Res. 2016, 37, 127-141. [CrossRef]

16. Foster, M.S. Rhodoliths: Between Rocks and Soft Places. J. Phycol. 2001, 37, 659-667. [CrossRef]

17. Pinheiro, H.T.; Martins, A.S. Estudo comparativo da captura artesanal do camarão sete-barbas e sua fauna acompanhante em duas áreas de pesca do litoral do estado do Espírito Santo, Brasil. Bol. Inst. Pesca São Paulo 2009, 35, 215-225. (In Portuguese)

18. Pinheiro, H.T.; Joyeux, J.C. Pescarias multi-específicas na região da Foz do Rio Doce, ES, Brasil: Características, problemas e opções para um futuro sustentável. Braz. J. Aquat. Sci. Technol. 2007, 11, 15-23. (In Portuguese) [CrossRef]

19. Netto, R.F.; Beneditto, A.P.M.D. Diversidade de artefatos da pesca artesanal marinha do Espírito Santo. Biotemas 2007, 20, 107-119. (In Portuguese)

20. Pinheiro, H.T.; Cordeiro Madureira, J.M.; Joyeux, J.-C.; Martins, A.S. Fish diversity of a southwestern Atlantic coastal island: Aspects of distribution and conservation in a marine zoogeographical boundary. Check List 2015, 11, 1-17. [CrossRef]

21. Posamentier, H.W.; Jervey, M.T.; Vail, P.R. Eustatic Controls on Clastic Deposition I-Conceptual Framework. Soc. Econ. Paleontol. Mineral. Spec. Publ. 1987. [CrossRef] 
22. Posamentier, H.W.; Allen, G.P. Variability of the sequence stratigraphic model: Effects of local basin factors. Sediment. Geol. 1993, 86, 91-109. [CrossRef]

23. Dominguez, J.M.L. The coastal zone of Brazil. In Geology and Geomorphology of Holocene Coastal Barriers of Brazil; Lecture Notes in Earth Sciences; Sergio, R.D., Hesp, P.A., Eds.; Springer-Verlag: Berlin/Heidelberg, Germany, 2009; pp. 17-51.

24. Dominguez, J.M.L.; da Silva, R.P.; Nunes, A.S.; Freire, A.F.M. The narrow, shallow, low-accommodation shelf of central Brazil: Sedimentology, evolution, and human uses. Geomorphology 2013, 203, 46-59. [CrossRef]

25. Araújo, T.C.M.D.; Santos, R.C.D.A.L.; Seoane, J.C.S.; Seoane, J.C.S. Erosão e Progradação do litoral de Alagoas. In Erosão e Progradação do Litoral do Brasil; Muehe, D., Ed.; Minstério de Meio Ambiente: Brasilia, Brazil, 2006; Volume 1, pp. 197-212. (In Portuguese)

26. Baker, E.K.; Harris, P.T. 2-Habitat Mapping and Marine Management. In Seafloor Geomorphology as Benthic Habitat; Elsevier: London, UK, 2012; pp. 23-38.

27. Freire, A.F.M.; Dominguez, J.M.L. A seqüência holocênica da plataforma continental central do Estado da Bahia. Bol. Geociênc. Petrobras 2006, 14, 247-267. (In Portuguese)

28. Amado-Filho, G.M.; Moura, R.L.; Bastos, A.C.; Salgado, L.T.; Sumida, P.Y.; Guth, A.Z.; Francini-Filho, R.B.; Pereira-Filho, G.H.; Abrantes, D.P.; Brasileiro, P.S.; et al. Rhodolith beds are major $\mathrm{CaCO}_{3}$ bio-factories in the tropical South West Atlantic. PLoS ONE 2012, 7, 41-45. [CrossRef] [PubMed]

29. Milliman, J.D. Role of Calcareous Algae in Atlantic Continental Margin Sedimentation. In Fossil Algae: Recent Results and Developments; Flügel, E., Ed.; Springer: Berlin/Heidelberg, Germany, 1977; pp. 232-247.

30. Amado-Filho, G.M.; Bahia, R.G.; Pereira-Filho, G.H.; Longo, L.L. South Atlantic rhodolith beds: Latitudinal distribution, species composition, structure and ecosystem functions, threats and conservation status. In Rhodolith/Maërl Beds: A Global Perspective; Riosmena-Rodríguez, R., Nelson, W., Aguirre, J., Eds.; Springer: Boca Raton, FL, USA, 2017; pp. 299-317.

31. Bahia, R.G.; Abrantes, D.P.; Brasileiro, P.S.; Pereira-Filho, G.H.; Amado-Filho, G.M. Rhodolith bed structure along a depth gradient on the northern coast of bahia state, Brazil. Braz. J. Oceanogr. 2010, 58, 323-337. [CrossRef]

32. Brasileiro, P.S.; Pereira-Filho, G.H.; Bahia, R.G.; Abrantes, D.P.; Guimarães, S.M.P.B.; Moura, R.L.; Francini-Filho, R.B.; Bastos, A.C.; Amado-Filho, G.M. Macroalgal composition and community structure of the largest rhodolith beds in the world. Mar. Biodivers. 2016, 46, 407-420. [CrossRef]

33. Amado-Filho, G.; Maneveldt, G.; Pereira-Filho, G.; Manso, R.C.C.; Bahia, R.; Barros-Barreto, M.B.; Guimarães, S. Seaweed diversity associated with a Brazilian tropical rhodolith bed. Cienc. Mar. 2010, 36, 371-391. [CrossRef]

34. Steller, D.L.; Foster, M.S. Environmental factors influencing distribution and morphology of rhodoliths in Bahía Concepción, BCS, México. J. Exp. Mar. Biol. Ecol. 1995, 194, 201-212. [CrossRef]

35. Foster, M.S.; Riosmena-Rodriguez, R.; Steller, D.L.; Woelkerling, W.J. Living rhodolith beds in the Gulf of California and their implications for paleoenvironmental interpretation. In Pliocene Carbonates and Related Facies Flanking the Gulf of California, Baja California, Mexico; Johnson, M.E., Ledesma-Vázquez, J., Eds.; Geological Society of America: Boulder, CO, USA, 1997; pp. 127-139.

36. Steller, D.L.; Riosmena-Rodríguez, R.; Foster, M.S.; Roberts, C.A. Rhodolith bed diversity in the Gulf of California: The importance of rhodolith structure and consequences of disturbance. Aquat. Conserv. Mar. Freshw. Ecosyst. 2003, 13, S5-S20. [CrossRef]

37. Littler, M.M.; Littler, D.S.; Dennis Hanisak, M. Deep-water rhodolith distribution, productivity, and growth history at sites of formation and subsequent degradation. J. Exp. Mar. Biol. Ecol. 1991, 150, 163-182. [CrossRef]

38. Amado-Filho, G.M.; Pereira-Filho, G.H. Rhodolith beds in Brazil: A new potential habitat for marine bioprospection. Rev. Brasil. Farm. 2012, 22, 782-788. [CrossRef]

39. Guimarães, S.M.P.B. A revised checklist of benthic marine Rhodophyta from the state of Espírito Santo, Brazil. Bol. Inst. Bot. 2006, 17, 145-196.

40. Amado-Filho, G.M.; Maneveldt, G.W.; Manso, R.C.C.; Marins-Rosa, B.V.; Pacheco, M.R.; Guimarães, S.M.P.B. Estructura de los mantos de rodolitos de 4 a 55 metros de profundidad en la costa sur del estado de Espírito Santo, Brasil. Cienc. Mar. 2007, 33, 399-410. (In Portuguese) [CrossRef] 
41. Pimentel, C.R.; Joyeux, J.C. Diet and food partitioning between juveniles of mutton Lutjanus analis, dog Lutjanus jocu and lane Lutjanus synagris snappers (Perciformes: Lutjanidae) in a mangrove-fringed estuarine environment. J. Fish Biol. 2010, 76, 2299-2317. [CrossRef] [PubMed]

42. Simon, T.; Pinheiro, H.T.; Moura, R.L.; Carvalho-Filho, A.; Rocha, L.A.; Martins, A.S.; Mazzei, E.; Francini-Filho, R.B.; Amado-Filho, G.M.; Joyeux, J.C. Mesophotic fishes of the Abrolhos Shelf, the largest reef ecosystem in the South Atlantic. J. Fish Biol. 2016, 89, 990-1001. [CrossRef] [PubMed]

43. Erikstad, L.; Bakkestuen, V.; Bekkby, T.; Halvorsen, R. Impact of scale and quality of digital terrain models on predictability of seabed terrain types. Mar. Geodesy 2013, 36, 2-21. [CrossRef]

C 2018 by the authors. Licensee MDPI, Basel, Switzerland. This article is an open access article distributed under the terms and conditions of the Creative Commons Attribution (CC BY) license (http://creativecommons.org/licenses/by/4.0/). 